\title{
ソフトな高分子複合体によるバイオ分子の構造・機能制御
}

\section{Soft Polymer Complexes to Engineer Biopolymer Assemblies and Functions}

\section{丸山 厚}

東京工業大学生命理工学院

T 226-8501

横浜市緑区長津田町 4259

B-57

Atsushi MARUYAMA

Department of Life Science and

Technology, Tokyo Institute of

Technology

Nagatsuta 4259 B-57, Midori, Yokohama 226-8501, Japan
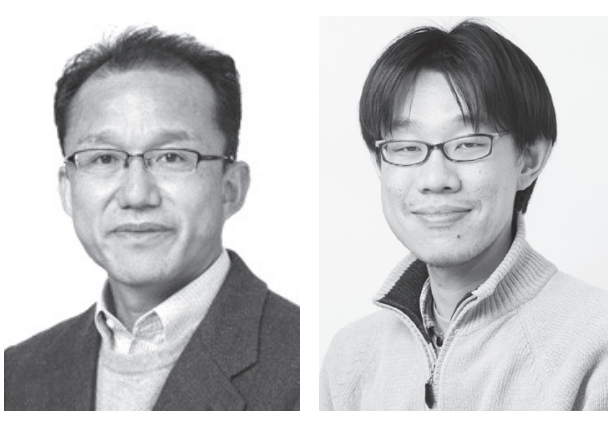

論文要旨：生体高分子は，特定の高次構造（Native な構造）に折りたたまれ（フォールディング），場合 によっては多分子組織化（アッセンブリング）し，多岐な生体機能を発現する。我々は，生体高分子の構造 形成を制御することを目的に，イオン電荷を持つ主鎖と親水性の側鎖からなるくし型共重合体を設計した。 共重合体は，反対電荷を持つ生体高分子と可溶性の高分子電解質複合体（IPEC）形成を介し，生体高分子 間の静電反発を抑制し，その構造形成を促した。たとえば核酸の二重鎖，三重鎖および四重鎖形成速度を共 重合体は顕著に高めた。共重合体のこのような効果は，分子ビーコンや核酸酵素などの機能性核酸の活性を 高めるのに有用であった。共重合体は，電荷を持つペプチドのフォールディングも促しその機能を向上させ た。脂質膜破壊活性を持つ E5 ペプチドの活性な構造への転移を促し，その膜破壊活性を顕著に高めること がわかった。イオン性くし型共重合体を基盤としたソフトで可溶性の IPEC 形成は，生体高分子の活用を広 げると期待される。

\begin{abstract}
Correct folding and assembling are essential for biopolymers to exhibit their inherent biological activities. We have designed ionic comb-type copolymers consisting of a polyion backbone and hydrophilic graft chains to engineer folding and assembling of biopolymers, such as DNA and peptides, having opposite ionic charges. The cationic copolymer formed soluble and soft inter-polyelectrolyte complex (IPEC) with DNA and acidic peptides. The copolymers significantly facilitate nucleic acid assembly including DNA duplex, triplex and quadruplex formations. Activities of functional DNAs such as molecular beacons and DNAzymes were enhanced by the copolymer. The cationic comb-type copolymers also facilitated folding of peptides having anionic charges. E5 peptide, a membrane active peptide, was folded into alpha-helical structure by the added copolymer. The copolymer/peptide mixture showed stronger membrane disrupting activity than peptide alone. Soluble and soft IPECs produced with the ionic comb-type copolymer are promising to improve function and applications of biopolymers.
\end{abstract}

Key words: inter polyelectrolyte complex, comb-type copolymer, DNA, peptide, folding

\section{1 はじめに}

生体高分子は人工の高分子では到底真似の出来ない優 れた機能を発現する。それらには，触媒機能，分子認識 機能，情報伝達機能，物質輸送機能などが含まれる。生 体高分子のこれらの機能を利用し，産業や医療に活かす ことは古くから行われており，様々な人工分子との複合

連絡者：丸山 厚

E-mail : amaruyama@bio.titech.ac.jp
化による機能付加を目指したバイオコンジュゲート化学 の概念も確立されている。

タンパク質や核酸（特にRNA）などの生体高分子は, 特定の高次構造 (Native な構造)に折りたたまれ(フォー ルデイング），時には多分子組織化（アッセンブリング） し, 分子認識, 触媒, 情報伝達などの機能を発現する (Fig. 1)。逆に，高次構造が乱れるとその活性が失われる。 このような状態を変性状態と呼んでいる。生体内では分 子シャペロンと呼ばれるタンパク質が核酸やタンパク質 


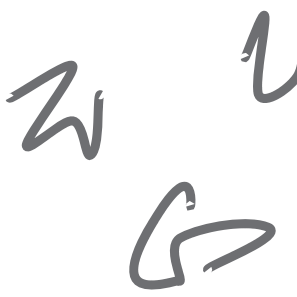

変性状態

(準安定、多型)

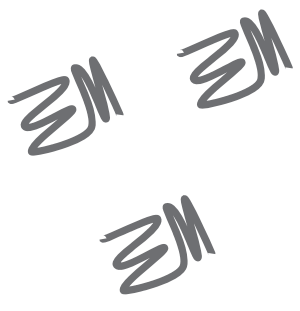

ネイティブ状態

(最安定、単型)
折りたたみや集合に使わ れる相互作用

- 疎水性相互作用

- 静電相互作用

・イオン間相互作用

・水素結合

- 双極子相互作用

・ファンデルワールスカ

・ロンドン分散力

- 疎水性相互作用

・ スタッキング相互作用

- 共有結合

Fig. 1 生体高分子の折りたたみをそれに働く分子間力

のフォールディングやアッセンブリングを介助してい る。著者らは，生体分子の折りたたみや集合体形成を合 成高分子との複合体形成を介して制御し，その機能を高 める試みを, 特に高分子電解質複合体 (IPEC) に着目 して検討してきた。本稿では，核酸やペプチドを対象と した例を紹介する。

\section{2 ソフトな高分子電解質複合体の設計と核酸ハイブ リッドの形成制御}

Fig. 1 に示すように, 生体高分子の高次構造は疎水性 相互作用, 静電的相互作用, 水素結合などの非共有結合 的な相互作用などが多点で働くことで形成・安定化され ている。なかでもタンパク質では，疎水的な相互作用が フォールディングや変性の駆動力として重要な働きをし ている。DNA や RNA のような核酸は, 繰り返し単位 毎にリン酸基をもつ。高い密度で負電荷を持ち，その高 分子電解質としての特性がフォールデイングやアッセン ブリングに強く影響する。これは，対イオン凝縮理論に よって説明されているが，端的に言えば，同じ電荷が高 密度になる構造（コンフォメーション）は低密度のもの に比べ不安定となる。共存する塩の濃度が高くなると静 電反発が遮蔽されその安定性の差は小さくなる。具体的 に核酸の二重らせん形成（ハイブリダイゼーション）を 例にとると，二重らせん状態ではリン酸イオン基の密度 が単鎖の時より高くなるので，高分子電解質としての性 質からは二重らせん形成は不利な構造となる。しかし $\mathrm{NaCl}$ や $\mathrm{MgCl}_{2}$ などの共存塩を増やすことで, 二重らせ んが安定化される。この時, 一価の $\mathrm{Na}$ イオンより二価 の $\mathrm{Mg}$ イオンがより低濃度で働く。より多価のカチオン, つまりカチオン性の高分子 (ポリカチオン) を用いれば, より効果的に二重らせん形成を促進できるはずである。 答えは, イエスでありノーである。ポリリシンをはじめ
とするポリカチオンはナノモルオーダー以下の極めて低 濃度でも核酸と IPEC を形成し, 低濃度でも核酸間の静 電反発が遮蔽できる。しかし, 複合体は脱水和, コンパ クトな形態に凝縮し，不溶化する。既に二重らせんを形 成していれば不溶化するものの結果的には二重らせんが 安定化する。一方，二重らせんを形成する核酸のそれぞ れが単鎖状態で IPEC 形成し不溶化すれば，単鎖間の出 会う頻度は著しく低下し, 二重らせん形成は困難とな る。したがって, ポリカチオンを利用し核酸の構造形成 を制御するためには，ポリカチオンの性質に工夫を加え る必要が生じる。1つは, IPEC 形成時の溶解性の向上, もう 1 つはポリカチオンと核酸との相互作用が核酸の特 異的な認識や構造形成を損なわないようにする点であ る。ポリカチオンと核酸との IPEC の性状を制御するた めに, Fig. 2 に示すようなくし型共重合体を設計した。 親水性の高分子をイオン性の高分子鎖の主鎖に枝状に配 することで, 核酸との IPEC の可溶性を高めるとともに, ポリカチオン主鎖と核酸との相互作用を側鎖により調整 する狙いである。ポリリシン（PLL）をカチオン性主鎖， デキストラン（Dex）を親水性の側鎖とした場合，共重 合体中のデキストランの重量組成を $80 \%$ 以上にした時, 凝縮を伴わない可溶性の IPEC が得られた ${ }^{1)}$ 。一分子観 察からは核酸のランダムコイル状の溶存状態が, 円二色 性（CD）スペクトルからは核酸の二次構造が，それぞ れ複合体を形成しても保持されていることが確認され た。PLLと Dex からなるくし型共重合体 (PLL-g-Dex) をDNA 集合体の安定性に与える効果を検討したとこ 万, 共重合体は二重らせん DNA の融解温度を約 $20^{\circ} \mathrm{C}$, 三重らせんは約 $50^{\circ} \mathrm{C}$ 高めることがわかった ${ }^{2)}$ 。さらに 共重合体の効果を, 熱力学的扮よび速度論的に検討した 結果, 共重合体は核酸ハイブリッドの形成速度を高め, 安定化することがわかった ${ }^{3)}$ 。核酸の化学修飾など様々 


\section{・ 親水性側鎖を配したイオン性く し型共重合体}

\section{i. 反対電荷を有する生体高分子と可 溶性高分子電解質複合体の形成 \\ ii. 生体高分子のイオン間反発の遮蔽 \\ iii. 生体高分子の折りたたみ、集合の 促進}

iv. 生体高分子の機能制御

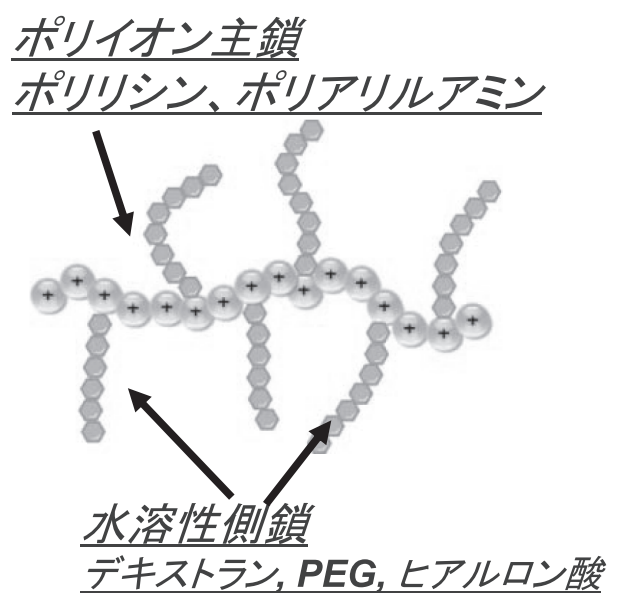

Fig. 2 イオン性くし型共重合体によるソフトな高分子電解質複合体形成

な手法で核酸ハイブリッドの安定化が試みられている が，その多くはハイブリッド解離速度を低下させるもの であり，共重合体に見られた速度論的効果はきわめてユ ニークなものである ${ }^{4)}$ 。核酸ハイブリッドの安定性に与 える共存塩濃度依存性は, 共重合体存在下では抑制され る。つまり，共重合体は核酸間の静電反発を抑制するこ とで，核酸をあたかも非イオン性の生体高分子として振 る舞わせることがわかった ${ }^{5)}$ 。

\section{3 くし型共重合体による機能性核酸の機能向上}

核酸は任意の塩基配列のものが容易に合成可能にな り, 核酸そのものを機能材料とする研究が幅広く展開さ れている。それらには，核酸の配列特異的な自己組織化 能を利用したものが多岐にわたる（Fig. 3）。もっとも頻 繁に利用される例が，核酸解析のために利用する核酸プ ローブだろう。ほかにも, 核酸のナノメートルオーダー での構造緻密性を利用したナノ構造体の構築, さらにハ イブリッド形成の可逆性を利用した核酸分子マシンや分 子コンピューター, 核酸そのものを医薬として活用する 核酸医薬がある。また生化学的機能として酵素活性や受 容体としての役割が，核酸に新たに見いだされており， 機能材料としての核酸は年々広がりを増している。これ ら機能性核酸の性能を向上させるために, 核酸ハイブ リッドの安定性の向上やその形成速度を高める手法が求 められるケースは多い。核酸プローブの一つに分子ビー コン（MB）がある（Fig. 4）。これは，両端に相補的な 配列をもつステムーループ型の核酸配列に，蛍光色素と 消光基を修飾したものである。ステムーループ状態では, 蛍光色素と消光基が近接することで，蛍光色素からの発 光が消光される。 $\mathrm{MB}$ と相補的な配列を持つ標的となる 核酸が存在すると，MB は標的核酸とハイブリッドを形 成する。この時, 蛍光色素と消光基が離れ, 蛍光が回復 する。つまり, 標的核酸を蛍光強度の変化として検出す
ることができる。分子ビーコン法の感度を高めるために， 浅沼らによりインステム型分子ビーコン (ISMB) が開 発された ${ }^{6)}$ 。従来の MB がステム末端に蛍光色素および 消光基を配しているのに対し，ステム内部に両者を配置 することで, 消光効果を高めるとともに蛍光色素 · 消光 基の数を増やすことが可能となり, 結果的に標的核酸に 対する検出感度が向上できる。 $\mathrm{MB}$ 法の共通の短所は, 標的核酸とのハイブリッド形成速度や形成率がステム構 造の存在により低くなり, 結果的に検出感度に制約を与 えることである。そこで, カチオン性共重合体 PLL-gDexにより MB 法のさらなる改善を検討した。その結 果を Fig. 5 に示す。共重合体を存在させた場合, $\mathrm{MB}$ と 標的核酸とのハイブリッド形成が概ね 100 倍と顕著に速 くなり，短時間で高いシグナルが得られた。結果的に， ISMB と共重合体を組み合わせることで, 最も高い感度 の $\mathrm{MB}$ システムが構成された ${ }^{7)}$ 。

DNA や RNA からなる核酸酵素も様々な応用が期待 される機能性核酸である。とりわけDNA からなる核酸 酵素（Deoxyribozyme, DNAzyme）は, 調製が容易で 安価, 化学的・生化学的安定性が高く, 様々な化学修飾 もしやすい点で注目されている。なかでも RNA 切断活 性，つまりリボヌクレアーゼ活性を持つ DNAzyme は, 高い酵素活性を発現するものが試験管内進化法により取 得されており, 核酸医薬, バイオセンサーなどへの応用 が精力的に取り組まれている。リボヌクレアーゼ活性を 持つDNAzymeの反応経路を Fig. 6 に示す。まず, DNAzyme の基質結合アームが基質となる RNA 配列と ハイブリッドを形成し, 酵素・基質複合体（ES）を形 成する。その後，2価カチオン $\left(\mathrm{M}^{2+}\right)$ を補触媒として， 基質 RNA を配列特異的に切断する。次に, 酵素 - 生成 物（EP）が解離し， DNAzyme は新たな基質と ES を 形成することで切断反応を繰り返す。これまでに得られ ている DNAzymeは, 基質に対して酵素が過剩に存在 


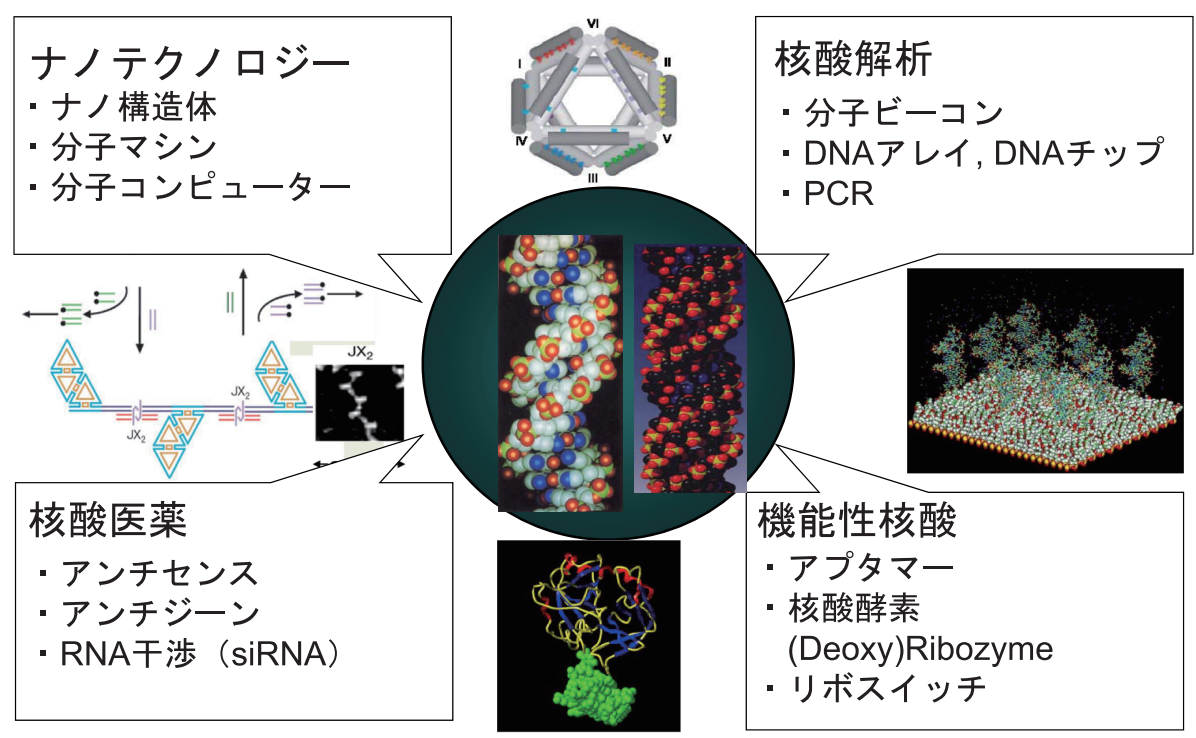

Fig. 3 核酸のナノ (バイオ) テクノロジーへの応用

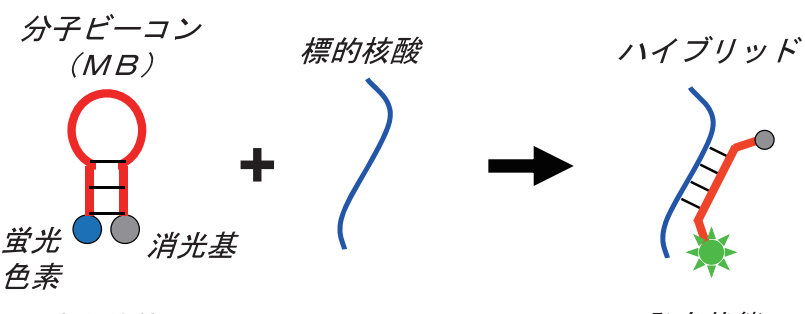

消光状態

Fig. 4 核酸プローブとしての分子ビーコン

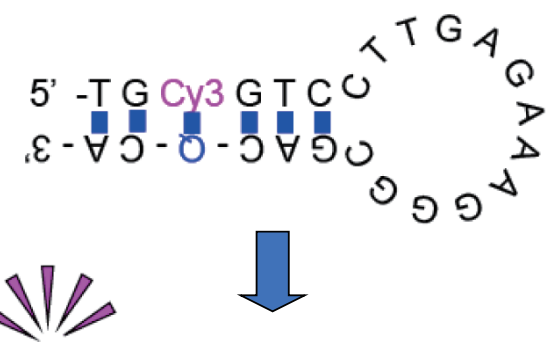

\section{5'-TG-CY3-GTCCTTGAG-AAAGGGCGAC-Q-CA-3' $3^{\prime}-A C$ - CAGGAACTC-TTTCCC G-5'}

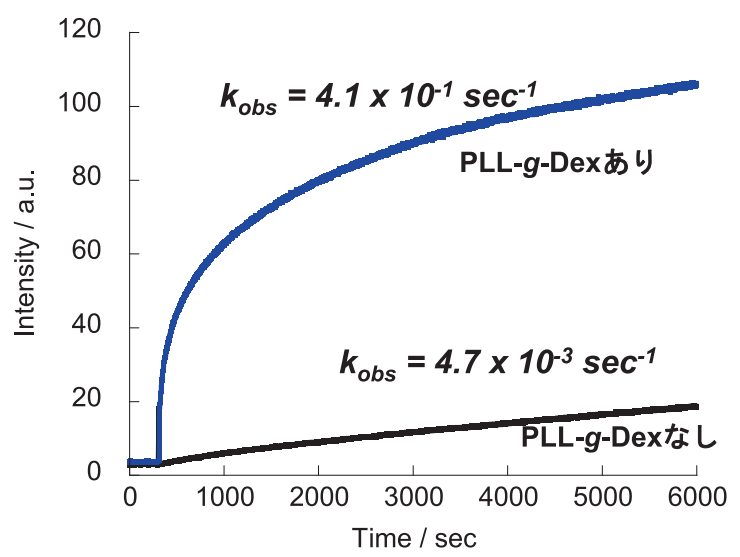

Fig. 5 MB 法に拈けるカチオン性くし型共重合体（PLL-gDex）の促進効果

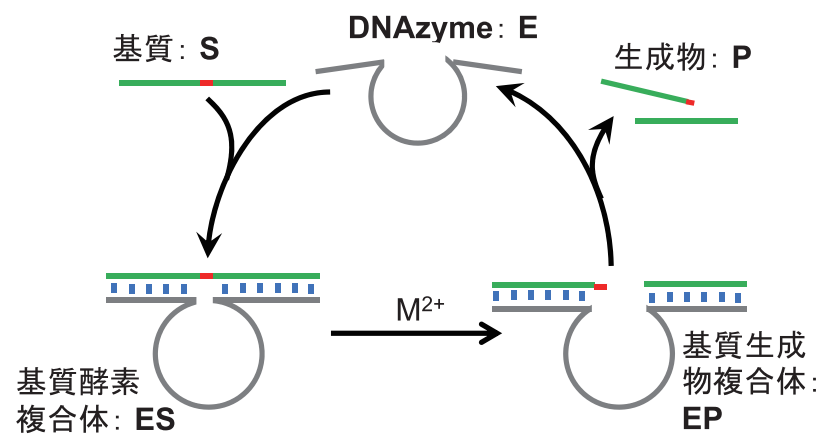

Fig. 6 リボヌクレアーゼ活性を持つ DNAzyme の反応経路

する条件では，高い酵素活性を示す。一方，基質が酵素 に対して過剩に存在する条件下では，活性が大きく低下 するものが多い。これは, EP が安定なため, その解離 が遅く，酵素のターンオーバー効率が低いことに起因す る。EP の解離は，反応温度を高めることで速めること が可能であるが，温度を上げると ES の形成速度が低下 するというジレンマに陥る。DNAzyme 反応のターン オーバー効率を高めるためには，核酸ハイブリッドの形 成・解離のダイナミクスを速める手法が必要となる。す でにPLL-g-Dexには，こうしたハイブリッド形成のダ イナミクスを高めることが見いだされて扮り ${ }^{8)}$, DNAzyme 反応のターンオーバー効率を高める上でも有 効と推測された。そこで, PLL- $g$-Dex の DNAzyme 反 応に与える効果を検討した。その結果, 共重合体は, 酵 素過剩な条件下では酵素反応に影響しないものの, 基質 過剩条件下では酵素反応速度を顕著に促進し, PLL-gDexがターンオーバー過程を速めることが明らかとなっ た ${ }^{9)}$ 。さらに, 共重合体の効果を, DNAzyme 反応を利 用した核酸センサー（MNAzyme）にも適用した。 MNAzyme は, 標的核酸の存在を, 酵素反応を利用し 


\section{PLL-g-Dexなし}

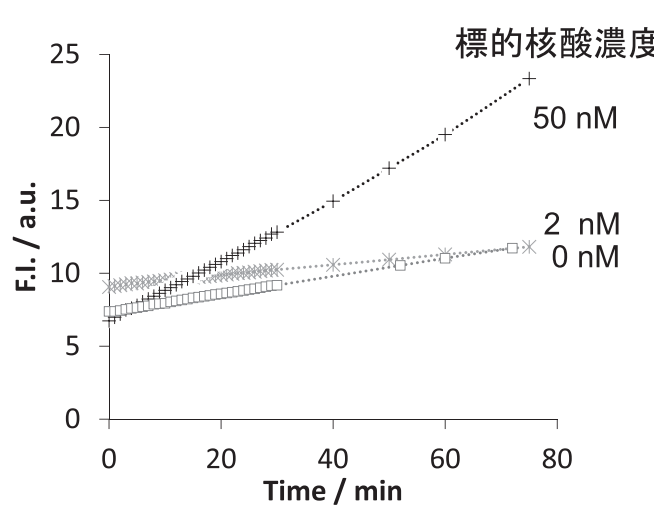

PLL-g-Dexあり

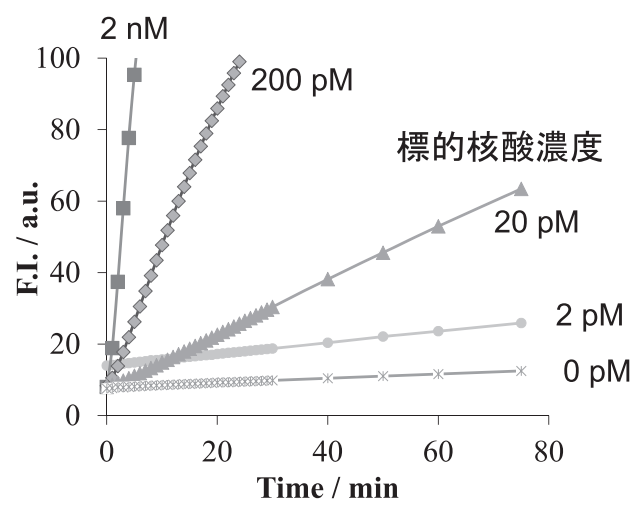

Fig. 7 MNAzyme 型核酸センサーに対するカチオン性くし型共重合体の効果

て化学増幅しつつ検出することができる核酸からなる核 酸センサー分子である。核酸の検出反応では，PCR が シグナル増幅できる手法として頻繁に利用されている が, PCRにはタンパク質酵素, ヌクレオチド三リン酸 など低温保存が必要な試薬のほか, サーマルサイクラー と呼ばれる装置による厳密な加熱・冷却制御が不可欠で ある。一方, MNAzyme 型のセンサーは, 核酸配列の みで構成され, 温度制御も単純で良い。つまり, 検査機 関外の Point-of-Care での検査が可能となり, 水際での 感染症対策等に有利である。Fig. 7 は, 標的となる核酸 の濃度を変化させ, MNAzyme 反応を共重合体存否で 比較した結果である。共重合体PLL- $g$-Dexの不在下では, $50 \mathrm{nM}$ の標的核酸を辛うじて検出できるが, $2 \mathrm{nM}$ では バックグラウンドシグナルと判別不能であった。これに 対して, 共重合体存在下では, $2 \mathrm{nM}$ 標的核酸を数分で, $20 \mathrm{pM}$ の標的も数十分で検出可能となり, 共重合体を存 在させることで MNAzyme 型核酸センサーの感度を数 100 倍高められることが見いだされた ${ }^{10)}$ 。このほかにも 共重合体は，核酸夕イピング法 ${ }^{11)}$ や核酸ナノマシン ${ }^{12)}$ の機能向上にも有用であることがわかっている。

\section{4 カチオン性くし型共重合体によるぺプチド構造・機 能制御}

核酸で見出された共重合体の機能は, 核酸以外の生体 高分子にも展開可能と考えられた。そこで, 多価の負電 荷をもつペプチドに着目した。E5ペプチドは, インフ ルエンザウィルスの膜タンパク質であるへマグルチニン の脂質膜破壊部位を模倣した 20 アミノ酸残基からなる 酸性ペプチドで， 5 残基のグルタミン酸を含む酸性ペプ チドである。インフルエンザウィルスは, この細胞膜破 壊活性を利用して細胞内へと感染する。E5 は, 中性 pH ではランダムコイル構造であるが, 酸性 $\mathrm{pH}$ ではグルタ ミン酸側鎖のカルボキシル基のイオン解離が抑えられ,

\section{E5: GLFEEAIAEEFIEGGWEEGLIEEG}
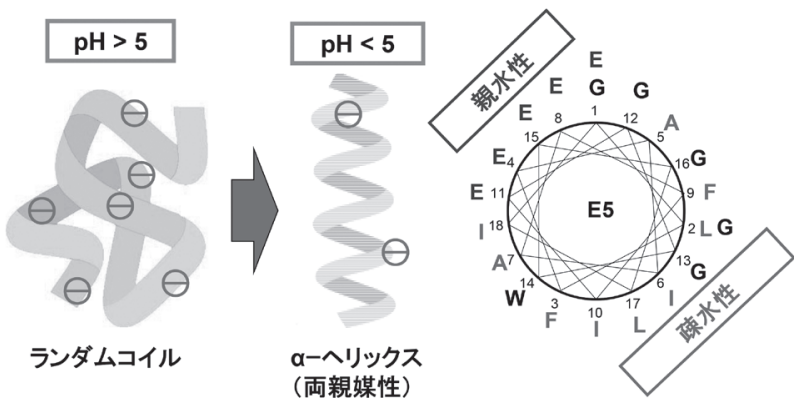

Fig. 8 脂質膜破壊活性を持つ E5 ペプチドの構造

静電反発の解消とともに $\alpha$-ヘリックス構造に転移す る。この時, 両親媒性のヘリックス構造を形成すること で膜破壊活性を発現する（Fig. 8)。近年核酸医薬やタン パク質医薬が注目されているが, その中には細胞内への 送達を必要とするものも多い。E5のような脂質膜破壊 性ペプチドは, ドラッグデリバリーの研究領域では, 細 胞内デリバリーの分子ッールとしてその利用が検討され ている。しかし, これらのペプチドは, 元来疎水性が高 いことで溶解性にそしく, 酸性下では凝集するとともに ヘリックス構造への転移が阻害され, 結果的にその機能 も低下してしまう問題点がある。つまり，E5ペプチド の膜破壊活性を高めるためには，溶存性を維持したまま で両親媒性へリックス構造への転移を促す必要があると 考えられた。そこで, 反対の電荷を持つカチオン性くし 型共重合体によりペプチドの構造転移を促し, 機能の向

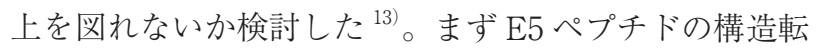
移に及ぼす共重合体の効果を調べた。Fig. 9 には円二色 性（CD）スペクトルにより $\mathrm{E} 5$ ペプチドの構造を調べ た結果を示す。 $\mathrm{E} 5$ ペプチド溶液の $\mathrm{pH}$ を中性から徐々 に低下させると, $220 \mathrm{~nm}$ での CD シグナルはやや負に 強くなるが, 明確な $\alpha$-ヘリックスを示すシグナルは見 られなかった。一方で溶液の散乱が強まりペプチドが酸 
性化に伴い凝集・不溶化することが確認された。これに 対し，ペプチド溶液にカチオン性くし型共重合体（ポリ アリルアミン (PAA)-g-Dex) を加えていくと, CD シ グナルは典型的な $\alpha$-ヘリックスのパターンを示した。 このとき溶液の散乱は変わらず，共重合体がペプチドの 溶存性を保ちつつ $\alpha$-ヘリックスへと転移させたことを 示す。共重合体が E5 のグルタミン酸側鎖間の静電反発 を遮蔽し，中性 $\mathrm{pH}$ でもへリックスへの転移を促し，か つその溶存性をDex 側鎖の効果で維持させた結果であ る。共重合体は E5 ペプチドの活性構造への転移を促し, かつその溶存性を維持したことから，ペプチドの膜破壊 活性を高めることが期待される。そこで，脂質小胞（リ ポソーム）に対する膜破壊活性を調べた。Fig. 10 は, 色素を内包したリポソームからの色素の漏出により, 膜 破壊活性を調べた結果である。まず E5 が膜破壊活性を 示すといわれている pH5.4で調べると, 確かに E5 は色 素の漏出を促し, 膜を破壊することがわかる。しかし, その活性はくし型共重合体存在下で行うと, 顕著に高め
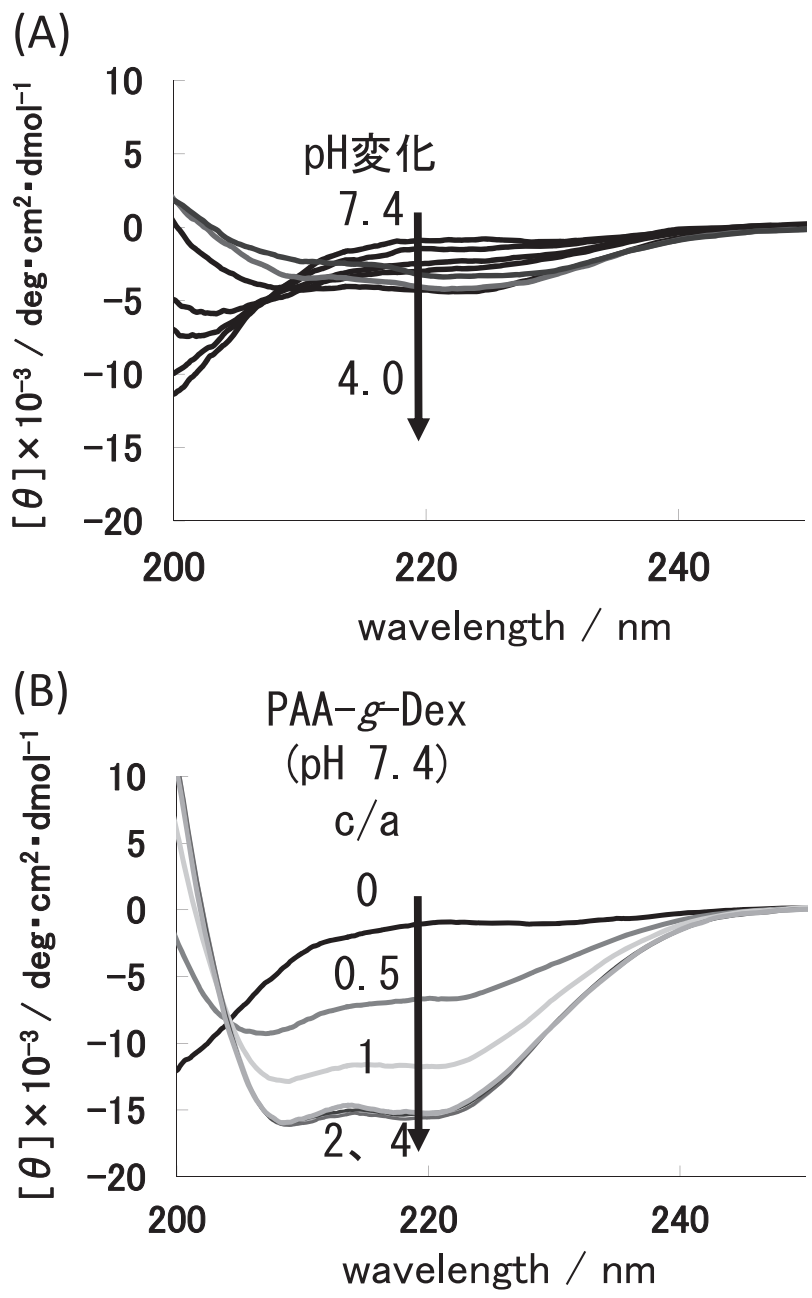

Fig. 9 E5 ペプチドの構造に及ぼすカチオン性くし型共重合 体 (PAA-g-Dex) の効果
られた。次に, 中性 $\mathrm{pH}$ で同様な実験を行った。E5は 中性 $\mathrm{pH}$ では全く膜破壊活性を示さなかったが, 共重合 体存在下では高い膜破壊活性が誘導された。共重合体が 溶存性とへリックスへの転移を促すことで E5 ペプチド の機能を高めた結果と考えられる。このような共重合体 のペプチド機能強化効果が, 細胞膜に対しても発揮され るか検討を加えた。Fig. 11 は，ヒト白血病細胞株 HL-60 細胞に対する細胞膜破壊活性を, 乳酸脱水素酵素の細胞 内からの漏出で調べた結果である。E5 のみでは pH5.4 においても膜破壊活性が見られないが, 共重合体が共存 すると強い活性が観察された。同様に，中性 $\mathrm{pH}$ でも E5 と共重合体存の共存下でのみ活性が見られた。いず れの $\mathrm{pH}$ でも $\mathrm{E} 5$ のペプチド配列をスクランブル化した E5sc E5 の代わりに用いると，全く活性が見られな くなり，共重合体が E5 のフォールディングや溶存性を 高め, その構造特異的な機能を増強したことが示される。

リポソーム膜と細胞膜の双方に対し共重合体がペプチ
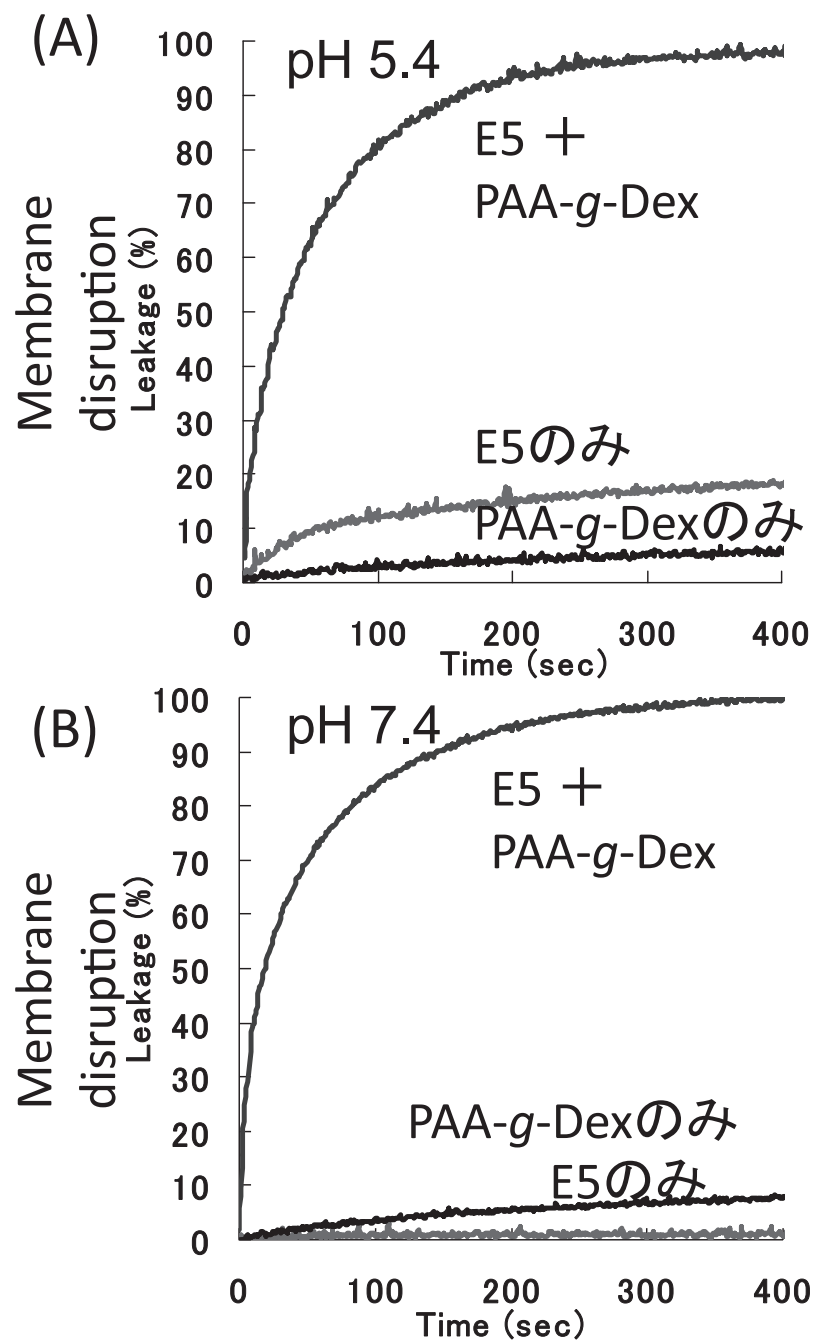

Fig. 10 E5 ペプチドの膜破壊活性に及ぼすくし型共重合体 の効果 
(A) $\quad \mathrm{pH} 5.4$

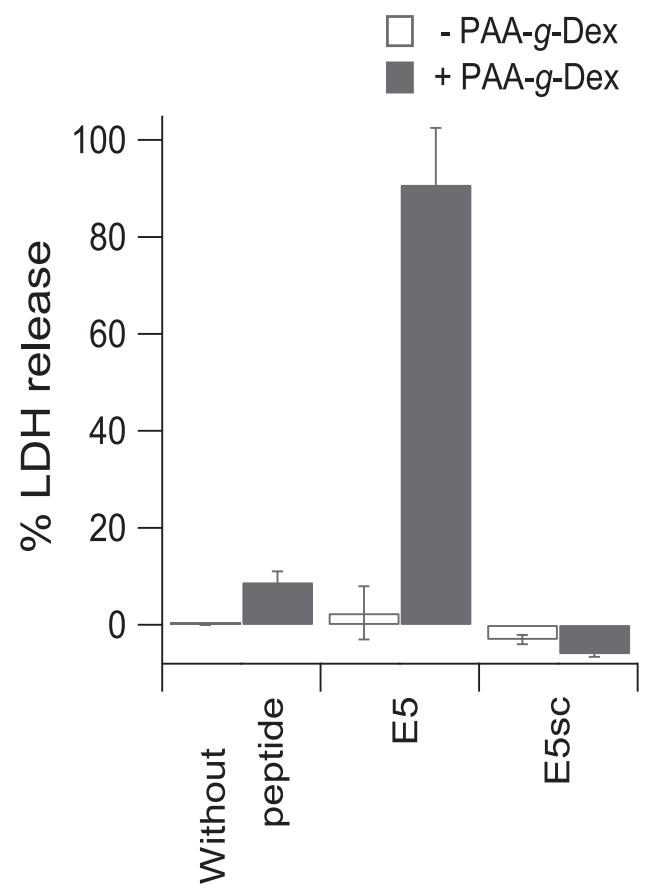

(B) $\quad \mathrm{pH} 7.4$
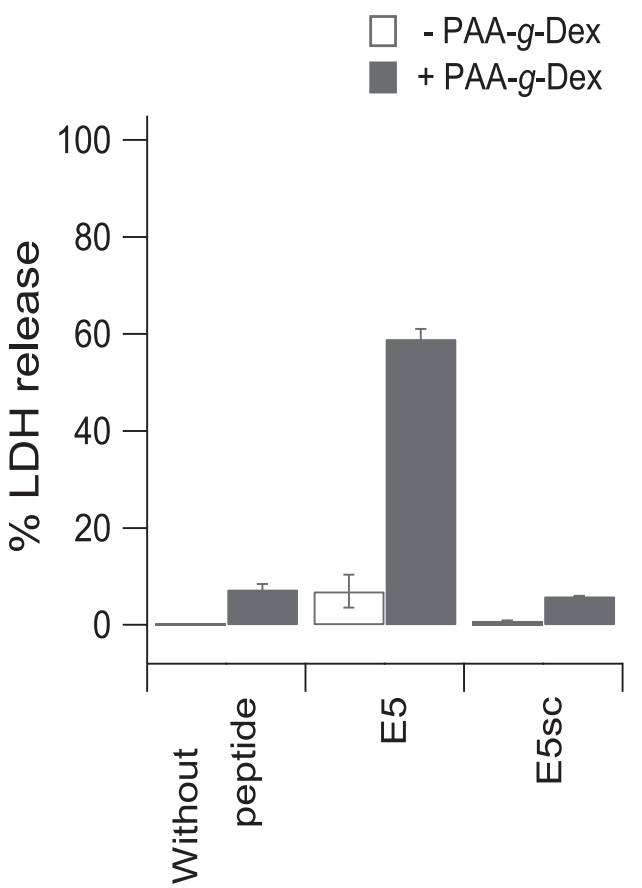

Fig. 11 E5 ペプチドの膜破壊活性に及ぼすくし型共重合体の効果

ド機能を強化することがわかった。興味深いことの $1 つ$ は，共重合体により E5 の活性を中性 $\mathrm{pH}$ 下でオン・オ フ制御できることである。新しい機能性ペプチドシステ ムとしての可能性が示唆される。実際, 共重合体とペプ チドの複合体を形成・解離することで, 脂質膜の構造を 可逆的に制御できることが見いだされている ${ }^{14)}$

最近は，医薬としてもぺプチドが注目されている。そ の際も, ペプチドのフォールディング制御と溶存性の維 持が課題となることが多い。共重合体で見いだされた機 能は,ペプチド医薬の領域にも波及できると考えられる。

\section{5 おわりに}

高分子電解質複合体の溶存性を高め， かつ生体高分子 との相互作用を制御する目的で，親水鎖を配したイオン 性くし型共重合体を設計した。単純な作業仮説であるが, 予想を超える効果を核酸やペプチドを対象として見いだ すことができた。これらの例で興味深い点は, くし型共 重合体は比較的強く生体高分子と相互作用するが，1） その相互作用が生体高分子独自の構造を損なわないこ と, 2) 共重合体と生体分子の相互作用が, 生体分子間, たとえば核酸間やペプチドと脂質膜間の相互作用を見か け上は阻害せず，むしろそれらの相互作用を促している 点である。DNAzyme で見れば, 共重合体は触媒活性に 必要な核酸の二次構造を損なわず, 同様に触媒活性に不 可欠な二価カチオンの核酸への配位に強く影響しない点
が挙げられる。くし型共重合体で形成される可溶性の複 合体の特徵は, 局所的には複合体の形成・解離を許す夕゙ イナミクスを持つソフトな一面であろう。このことで核 酸やペプチド自体の固有の分子特性を犠牲にすることな く，その機能を高めるものと推察される。このようなソ フトな高分子複合体の特徵を, さらに広く展開できれば と願っている。

\section{文 献}

1) Y. Sato, Y. Kobayashi, T. Kamiya, H. Watanabe, T. Akaike, K. Yoshikawa, A. Maruyama, Biomaterials, 26, 703 (2005). N. Sonda, M. Hirano, N. Shimada, A. Kano, S. Kidoaki, A. Maruyama, Chem. Lett., 40, 250 (2011). A. Maruyama, N. Sonda, K. Yamasaki, S. Kidoaki, N. Shimada, M. Maeshiro, M. Miyazaki, Curr. Nanosci., 10, 185 (2014).

2) A. Maruyama, M. Katoh, T. Ishihara, T. Akaike, Bioconjugate Chem., 8, 3 (1997). A. Maruyama, H. Watanabe, A. Ferdous, M. Katoh, T. Ishihara, T. Akaike, Bioconjugate Chem., 9, 292 (1998).

3) H. Torigoe, A. Ferdous, H. Watanabe, T. Akaike, A. Maruyama, J. Biol. Chem., 274, 6161 (1999). L. Wu, N. Shimada, A. Kano, A. Maruyama, Soft Matter, 4, 744 (2008).

4) H. Torigoe, A. Maruyama, J. Am. Chem. Soc., 127, 1705 (2005). H. Torigoe, A. Maruyama, S. Obika, T. Imanishi, T. Katayama, Biochemistry, 48, 3545 (2009).

5) A. Maruyama, Y. Ohnishi, H. Watanabe, H. Torigoe, A. 
Ferdous, T. Akaike, Colloids Surf. B, 16, 273 (1999).

6) H. Kashida, T. Takatsu, T. Fujii, K. Sekiguchi, X. Liang, T. Takase, Y. Yoshida, H. Asanuma, Angew. Chem. Int. Ed., 48, 7044 (2009). Y. Hara, T. Fujii, H. Kashida, K. Sekiguchi,X. G. Liang, K. Niwa, T. Takase, Y. Yoshida and H. Asanuma, Angew. Chem. Int. Ed., 49, 5502 (2010).

7) H. Asanuma, T. Osawa, H. Kashida, T. Fujii, X. Liang, K. Niwa, Y. Yoshida, N. Shimada, A. Maruyama, Chem. Commun., 48, 1760 (2012).

8) W. J. Kim, T. Ishihara, T. Akaike, A. Maruyama, Chem. Eur. J., 7, 176 (2001). W. J. Kim, T. Akaike, A. Maruyama, J. Am. Chem. Soc., 124, 12676 (2002). R. Moriyama, N. Shimada, A. Kano, A. Maruyama, Biomaterials, 32, 2351 (2011). R. Moriyama, N. Shimada, A. Kano, A. Maruyama, Biomaterials, 32, 7671 (2011).

9) J. Gao, N. Shimada, A. Maruyama, Biomater. Sci., 3,
308 (2015).

10) J. Gao, N. Shimada, A. Maruyama, Biomater. Sci, 3, 716 (2015).

11) W. J. Kim, Y. Sato, T. Akaike, A. Maruyama, Nat. Mater., 2, 815 (2003). K. Yamana, Y. Fukunaga, Y. Ohtani, S. Sato, M. Nakamura, W. J. Kim, T. Akaike, A. Maruyama, Chem. Commun., 19, 2509 (2005).

12) S. W. Choi, N. Makita, S. Inoue, C. Lesoil, A. Yamayoshi, A. Kano, T. Akaike, A. Maruyama, Nano Lett., 7, 172 (2007). J. Du, L. Wu, N. Shimada, A. Kano, A. Maruyama, Chem. Commun., 49, 475 (2013).

13) N. Shimada, H. Kinoshita, S, Tokunaga, T. Umegae, N. Kume, W. Sakamoto, A. Maruyama, J. Controlled Rel., 218, 45 (2015).

14) N. Shimada, H. Kinoshita, T. Umegae, S. Azumai, N. Kume, W. Sakamoto, M. Kaya, H. Higuchi, A. Maruyama, Manuscript in preparation. 